\title{
Perencanaan Sistem Plambing Air Buangan Gedung Rusunawa Mahasiswa Universitas Andalas
}

\author{
Puti Sri Komala $^{1}$, Suarni S. Abuzar ${ }^{2}$, Purnama Mentari Dewi ${ }^{3}$ \\ 1,2,3 Jurusan Teknik Lingkungan Fakultas Teknik Universitas Andalas, Padang \\ *Koresponden email: putisrikomala@eng.unand.ac.id
}

Diterima: 17 Juli 2019

Disetujui: 23 September 2019

\begin{abstract}
According to Indonesian National Standard (SNI) No.03-7065-2005, the building with more than 500 inhabitants, should prepare plumbing system design. The plumbing sewerage design of student flats building referred to SNI 03-6481- 2000 and SNI 03-7065-2005. Sewerage system for black- and grey water was discharged separately. Black water comes from the closet and the toilet clean out, while grey water comes from the lavatory, sink and floor drain. The wastewater flow rate is determined based on the plumbing fixtures. The sewage flowed partially full in horizontal pipe, and discharged into the standpipe in the the building shaft then flowed to the wastewater treatment plant i.e anaerobic-aerobic bioseptic tank. Grease traps are mounted at the sink to separate oils and fats. Each wastewater fixture is equipped with a fixture vent connected to the standpipe vent which extended through the roof to outdoors. Vent system consists of the vent circuit that connected to the toilet and the floor drain respectively, and the single vent that connected to the sink and the lavatory respectively. Black water sewerage pipes used 3-4 inches PVC, while the grey water sewerages used $1 \frac{1}{2}-21 \frac{1}{2}$ inches PVC, and vent used pipe 2-4 inches PVC.

Keywords: Plumbing sewerage system, Plumbing fixture, Indonesian National Standard (SNI) for Plumbing System, Students flats building, Vent

Abstrak

Berdasarkan Standard Nasional Indonesia (SNI) 03-7065-2005, gedung dengan penghuni lebih dari 500 orang harus mempunyai perancangan sistem plambing. Dalam perencanaan plambing air buangan ini standar yang diacu adalah SNI 03-6481- 2000 dan SNI 03-7065-2005. Perencanaan sistem plambing air kotor dan air bekas gedung dilakukan secara terpisah. Air kotor berasal dari kloset dan peturasan, sedangkan air bekas adalah air buangan yang berasal dari lavatory, sink dan floordrain. Laju aliran air buangan ditentukan berdasarkan beban unit alat plambing. Air buangan dialirkan dalam setengah penuh pada pipa mendatar menuju pipa tegak dalam shaft gedung, kemudian dialirkan menuju instalasi pengolahan air buangan yaitu tangki bioseptik. Grease trap dipasang pada sink untuk memisahkan minyak dan lemak. Saluran air buangan unit plambing dilengkapi dengan sistem ven yang dialirkan pada pipa tegak shaft menuju ke ruang terbuka lantai teratas. Sistem ven yang digunakan adalah ven sirkit untuk kloset dan floordrain, dan ven tunggal untuk sink dan lavatory. Pipa penyaluran air kotor yang digunakan yaitu pipa PVC 3 - 4 inci, air bekas PVC $1 \frac{112}{2}-2 \frac{1}{2} 2$ inci, dan ven menggunakan pipa PVC 2 - 4 inci.

Kata kunci: Gedung Rusunawa, Sistem Plambing Air Buangan, Standard Nasional Indonesia untuk Sistem Plumbing, Ven, Unit beban alat plambing
\end{abstract}

\section{Pendahuluan}

Universitas Andalas dalam rangka mendukung kegiatan mahasiswa dan meningkatkan fasilitas kampus terus melaksanakan pembangunan yang berkelanjutan. Salah satu fasilitas yang terus ditingkatkan oleh pihak kampus yaitu gedung asrama Universitas Andalas yang diperuntukkan bagi mahasiswa baru selama satu tahun pertamanya.

Melalui Kementerian Pekerjaan Umum, pada tahun 2014 Universitas Andalas mendapat bantuan berupa pembangunan satu unit twin block asrama. Gedung asrama baru Universitas Andalas yang diberi nama "Rusunawa Mahasiswa Universitas Andalas" ini dibangun setinggi 5 lantai pada lahan seluas \pm $1.410 \mathrm{~m}^{2}$ untuk kapasitas lebih dari 500 orang. Gedung asrama ini dibangun dengan berbagai fasilitas yang memadai diantaranya yaitu kamar asrama, difable room, dan ruang publik. Salah satu fasilitas yang harus ada dalam pembangunan gedung rusunawa ini yaitu sistem plambing yang baik.

Menurut SNI 03-7065-2005, perencanaan sistem plambing harus dilakukan untuk bangunan gedung dengan jumlah penghuni lebih dari 500 orang atau jumlah pengunjung lebih dari 1.500. Salah satu 
sistem plambing yang diperlukan adalah menyediakan sistem penyaluran air buangan tanpa mencemari bagian penting lainnya dalam bangunan serta penyaluran gas yang terbentuk dari air buangan tersebut juga diperlukan, agar tidak membahayakan kesehatan bagi penghuni yang ada di dalam gedung tersebut.

Berdasarkan penjelasan tersebut, perlu dilakukan suatu perancangan sistem plambing penyaluran air buangan mulai dari sumber menuju ke instalasi pengolahan limbah untuk diolah, sehingga air yang diolah memenuhi syarat dan standar yang telah ditetapkan untuk dibuang ke badan air. Sistem plambing air buangan yang direncanakan ini mengacu kepada standard dan peraturan plambing yang berlaku di Indonesia. Dalam makalah ini akan diberikan perhitungan tipikal perpipaan air buangan.

\section{Metode Penelitian}

\subsection{Standard dan Peraturan}

Perencanaan sistem plambing penyaluran air buangan mengacu kepada buku-buku pedoman, peraturan-peraturan mengenai plambing dan referensi pendukung lainnya. Peraturan yang digunakan adalah Standard Nasional Indonesia (SNI) 03-6481-2000 (Standar Nasional Indonesia, 2000) tentang Sistem Plambing-2000 dan Standard Nasional Indonesia (SNI) 03-7065-2005 tentang Tata Cara Perencanaan Sistem Plambing (Standar Nasional Indonesia, 2005).

\subsection{Pengumpulan Data Sekunder}

Pengumpulan data berupa gambar siteplan, denah dan tampak Gedung Rusunawa Mahasiswa Universitas Andalas, data informasi sumber air bersih yang digunakan, dan data lainnya yang terkait dengan proyek.

\subsection{Perencanaan Sistem Penyaluran Air Buangan dan Instalasi Pengolahan}

Sistem penyaluran air buangan terdiri dari penyaluran air kotor dan air bekas. Air kotor bersumber dari kloset, sedangkan air bekas berasal dari lavatory, sink dan floor drain. Langkah-langkah perencanaan sistem penyauran air buangan adalah sebagai berikut:

a. Perhitungan Penghuni Gedung

Penghuni gedung ditentukan berdasarkan luas lantai yang ada.

b. Perhitungan kuantitas air buangan

Berdasarkan jumlah penghuni dapat dihitung kuantitas air buangan yang dihasilkan yaitu sekitar $80 \%$

dari kebutuhan air bersih (Badan Standardisasi Nasional, 2006).

c. Penentuan jalur pipa air buangan

Berdasarkan lokasi alat plumbing di setiap lantai ditentukan jalur pipa air buangan yang akan dialirkan menuju ke shaft pipa tegak. Dari pipa tegak kemudian dialirkan menuju tangki pengolahan limbah di lantai dasar.

d. Penentuan jumlah unit beban alat plambing

Nilai beban masing-masing unit alat plambing dapat dilihat pada Tabel 1. Jumlah unit beban digunakan untuk menentukan laju aliran dan diameter pipa air buangan.

Tabel 1. Unit beban alat plambing untuk air buangan

\begin{tabular}{c|c|c}
\hline No & $\begin{array}{c}\text { Jenis Alat } \\
\text { Plambing }\end{array}$ & $\begin{array}{c}\text { Unit Alat Plambing } \\
\text { (UAP) }\end{array}$ \\
\hline 1 & Kloset & 4 \\
2 & Lavatory & 1 \\
3 & Sink & 4 \\
4 & Floor Drain & 0,5 \\
\hline \multicolumn{2}{c}{ Sumber: Morimura dan Noerbambang (2000) }
\end{tabular}

e. Penentuan diameter pipa

Pipa dari masing-masing alat plumbing tersebut dialirkan ke pipa air buangan mendatar dan pipa tegak. Penentuan ukuran pipa air buangan mendatar dilakukan berdasarkan beban maksimum pipa mendatar dan pipa tegak air buangan, dimana diameter pipa tersebut harus sama atau lebih besar dari diameter pipa minimum alat plambing (Tabel 2).

- Ukuran minimum pipa cabang mendatar

Pipa cabang mendatar sekurang-kurangnya harus sama dengan diameter terbesar dari perangkap alat plambing yang dilayani. Diameter minimum pipa air buangan untuk setiap alat plambing dapat dilihat pada Tabel 3.

- Kemiringan pipa

Kemiringan (slope) untuk pipa air buangan mendatar ditentukan berdasarkan diameter pipa air buangan seperti yang ditampilkan pada Tabel 4 . 
- Ukuran pipa tegak minimum

Pipa tegak harus mempunyai ukuran yang sekurang-kurangnya sama dengan diameter terbesar cabang mendatar yang disambungkan ke pipa tegak tersebut.

f. Pembuangan lemak

Sarana pembuangan lemak (Grease trap) berfungsi untuk menangkap minyak dan lemak yang terdapat pada air buangan sebelum dialirkan menuju unit pengolahan, untuk mencegah pengendapan minyak yang dapat menyumbat saluran air buangan dan memastikan agar aliran bebas setiap saat (American Society of Plumbing Engineers, 2012). Kapasitas grease trap ditentukan berdasarkan laju aliran air buangan alat plambing dan estimasi jumlah lemak yang disisihkan.

g. Unit pengolahan limbah

Unit pengolahan limbah menampung seluruh limbah dari pipa saluran air buangan. Air limbah yang dihasilkan dihitung berdasarkan 80\% kebutuhan air (Mara, 2004). Efluen yang dihasilkan diharapkan telah memenuhi baku mutu air limbah domestik menurut Peraturan Menteri Lingkungan Hidup No. 68 Tahun 2016 (Kementerian Lingkungan Hidup dan Kehutanan Republik Indonesia, 2016).

Tabel 2. Beban maksimum unit alat plambing untuk cabang horizontal dan pipa tegak air buangan

\begin{tabular}{|c|c|c|c|c|c|c|c|c|c|c|c|c|}
\hline \multirow{4}{*}{$\begin{array}{c}\text { D } \\
\text { Pipa } \\
\text { (inch) }\end{array}$} & \multicolumn{12}{|c|}{ Beban Maksimum Unit Alat Plambing yang Boleh disambung Kepada: } \\
\hline & \multirow{2}{*}{\multicolumn{3}{|c|}{ Cabang Mendatar ${ }^{1)}$}} & \multirow{2}{*}{\multicolumn{3}{|c|}{$\begin{array}{l}\text { Satu Pipa Tegak setinggi } 3 \\
\text { tingkat, atau untuk } 3 \text { interval }\end{array}$}} & \multicolumn{6}{|c|}{ Pipa Tegak dengan Tinggi Lebih dari 3 Tingkat } \\
\hline & & & & & & & \multicolumn{3}{|c|}{ Jumlah Untuk Satu Pipa Tegak } & \multicolumn{3}{|c|}{$\begin{array}{c}\text { Jumlah Untuk Cabang Satu } \\
\text { Tingkat }\end{array}$} \\
\hline & $\begin{array}{l}\text { Unit } \\
\text { Alat } \\
\text { Plam- } \\
\text { bing } \\
\text { (Prak- } \\
\text { tis) }\end{array}$ & $\begin{array}{c}\text { Re- } \\
\text { duksi } \\
(\%)\end{array}$ & $\begin{array}{l}\text { Unit Alat } \\
\text { Plam- } \\
\text { bing }^{2)} \\
\text { (NPC) }\end{array}$ & $\begin{array}{l}\text { Unit } \\
\text { Alat } \\
\text { Plam- } \\
\text { bing } \\
\text { (Prak- } \\
\text { tis) }\end{array}$ & $\begin{array}{c}\text { Re- } \\
\text { duksi } \\
(\%)\end{array}$ & $\begin{array}{l}\text { Unit Alat } \\
\text { Plamb- } \\
\text { ing }^{2)} \\
\text { (NPC) }\end{array}$ & $\begin{array}{l}\text { Unit } \\
\text { Alat } \\
\text { Plamb- } \\
\text { ing } \\
\text { (Prak- } \\
\text { tis) }\end{array}$ & $\begin{array}{c}\text { Re- } \\
\text { duksi } \\
(\%)\end{array}$ & $\begin{array}{l}\text { Unit Alat } \\
\text { Plam- } \\
\text { bing } \\
\text { (NPC) }\end{array}$ & $\begin{array}{c}\text { Unit } \\
\text { Alat } \\
\text { Plam- } \\
\text { bing } \\
\text { (Praktis) }\end{array}$ & $\begin{array}{c}\text { Re- } \\
\text { duksi } \\
(\%)\end{array}$ & $\begin{array}{c}\text { Unit Alat } \\
\text { Plambing } \\
\text { (NPC) }\end{array}$ \\
\hline $11 / 4$ & 1 & 100 & 1 & 2 & 100 & 2 & 2 & 100 & 2 & 1 & 100 & 1 \\
\hline $11 / 2$ & 3 & 100 & 3 & 4 & 100 & 4 & 8 & 100 & 8 & 2 & 100 & 2 \\
\hline 2 & 5 & 90 & 6 & 9 & 90 & 10 & 24 & 100 & 24 & 6 & 100 & 6 \\
\hline $21 / 2$ & 10 & 80 & 12 & 18 & 90 & 20 & 48 & 90 & 42 & 9 & 100 & 9 \\
\hline 3 & 14 & 70 & $20^{3)}$ & 27 & 90 & $30^{3)}$ & 54 & 90 & $60^{4)}$ & 14 & 90 & 16 \\
\hline 4 & 96 & 60 & 160 & 192 & 80 & 240 & 400 & 80 & 500 & 72 & 80 & 90 \\
\hline 5 & 216 & 60 & 360 & 432 & 80 & 540 & 880 & 80 & 1100 & 160 & 80 & 200 \\
\hline 6 & 372 & 60 & 620 & 78 & 80 & 960 & 1520 & 80 & 1900 & 280 & 80 & 350 \\
\hline 8 & 840 & 60 & 1400 & 1760 & 80 & 2200 & 2880 & 80 & 3600 & 480 & 80 & 600 \\
\hline 10 & 1500 & 60 & 2500 & 2660 & 70 & 3800 & 3920 & 70 & 5600 & 700 & 70 & 1000 \\
\hline 12 & 2340 & 60 & 3900 & 4200 & 70 & 6000 & 5880 & 70 & 8400 & 1050 & 70 & 1500 \\
\hline 15 & 3500 & 50 & 7000 & - & - & - & - & - & - & - & - & - \\
\hline
\end{tabular}

Sumber : Morimura dan Noerbambang (2000)

Catatan 1) Tidak termasuk cabang buangan gedung

2) NATIONAL PLUMBING CODE, American Standard, ASA 40.8-1995

3) Tidak lebih dari dua kloset

4) Tidak lebih dari tiga kloset

*1 Unit alat plambing praktis diterapkan kalau setiap alat plambing melayani 20 - 30 penghuni gedung, dan digunakan sistem ven lup

*2 Unit alat plambing dari NPC diterapkan kalau setiap alat plambing melayani 10 - 15 penghuni gedung, dan digunakan sistem ven individual

\subsection{Perencanaan Sistem Ven}

Sistem ven berfungsi untuk mensirkulasikan udara ke seluruh bagian sistem perpipaan air buangan agar sekat air dilindungi dari efek siphon dan tekanan balik. Perencanaan sistem ven tergantung dari alat plumbing yang dilayaninya, posisi dan fungsi sistem ven dalam perpipaan air buangan. Ukuran pipa ven ditentukan berdasarkan ketentuan yang terdapat pada Tabel 5 . 
Tabel 3. Diameter minimum perangkap dan pipa air buangan alat plambing

\begin{tabular}{clc}
\hline No & $\begin{array}{c}\text { Jenis Alat } \\
\text { Plambing }\end{array}$ & $\begin{array}{c}\text { Diameter Perangkap Mini- } \\
\text { mum }(\mathrm{mm})\end{array}$ \\
\hline 1 & Kloset & 75 \\
2 & Lavatory & 32 \\
3 & Sink & 50 \\
4 & Floor Drain & 40 \\
\hline
\end{tabular}

Sumber : Morimura dan Noerbambang (2000)

Tabel 4. Kemiringan pipa air buangan mendatar

\begin{tabular}{ccc}
\hline No & Diameter Pipa (mm) & Kemiringan Minimum \\
\hline 1 & 75 atau kurang & $1 / 50$ \\
2 & 100 atau kurang & $1 / 100$ \\
\hline
\end{tabular}

Sumber : Morimura dan Noerbambang (2000)

Tabel 5. Ukuran pipa cabang horizontal ven dengan lup

\begin{tabular}{|c|c|c|c|c|c|c|}
\hline \multirow{3}{*}{$\begin{array}{l}\text { Ukuran Pipa air } \\
\text { buangan (mm) }\end{array}$} & \multirow{3}{*}{$\begin{array}{l}\text { Unit alat plamb- } \\
\text { ing maksimum }\end{array}$} & \multicolumn{5}{|c|}{ Diameter ven lup ( mm ) } \\
\hline & & 40 & 50 & 65 & 75 & 100 \\
\hline & & \multicolumn{5}{|c|}{ Panjang max horizontal (m) } \\
\hline 40 & 10 & 6 & & & & \\
\hline 50 & 12 & 4,5 & 12 & & & \\
\hline 50 & 20 & 3 & 9 & 57 & & \\
\hline 75 & 10 & & 6 & 12 & 30 & \\
\hline 75 & 30 & & & 12 & 30 & \\
\hline 75 & 60 & & & 48 & 24 & \\
\hline 100 & 100 & & 2,1 & 6 & 15,6 & 60 \\
\hline 100 & 200 & & 1,8 & 5,4 & 15 & 54 \\
\hline 100 & 500 & & & 4,2 & 10,8 & 42 \\
\hline
\end{tabular}

Sumber : Morimura dan Noerbambang (2000)

\section{Hasil dan Pembahasan}

\subsection{Sistem Penyaluran Air Buangan dan Ven}

Gedung Rusunawa Mahasiswa Universitas Andalas yang dirancang untuk 562 penghuni ini memiliki 5 lantai dengn luas lantai $663 \mathrm{~m}^{2}$. Lantai pertama terdiri atas ruang publik, hall, difable room yaitu kamar bagi para penyandang cacat atau keterbatasan fisik serta fasilitas bersama. Lantai 2 sampai dengan lantai 5 merupakan lantai tipikal yang terdiri dari 23 kamar mahasiswa yang dilengkapi dengan tipikal toilet pribadi. Seluruh lantai memiliki toilet umum, dapur umum serta janitor sebagai fasilitas yang dapat dimanfaatkan bersama. Gedung ini memiliki ruangan shaft perpipaan yang berjumlah 12 unit (shaft A sampai shaft L), masing-masing shaft melayani 2 unit toilet.

Sistem penyaluran air buangan dirancang menggunakan sistem terpisah dimana air kotor dan air bekas masing-masing disalurkan dengan pipa yang berbeda. Sistem terpisah dipilih untuk mencegah terjadinya gangguan pada kinerja alat plambing. Jika salah satu pipa mengalami penyumbatan, maka gangguan tidak terjadi pada keseluruhan alat plambing. Selain itu juga karena pertimbangan estetika, yaitu untuk mencegah timbulnya bau tak sedap.

Sistem pengaliran air buangan yang digunakan adalah sistem pengaliran secara gravitasi, pengaliran dengan pompa sedapat mungkin dihindari (U.S. Department of Veterans Affair, 2014). Air buangan dialirkan dalam pipa pada kondisi $2 / 3$ penuh pipa mendatar dan menuju pipa tegak yang diletakkan dalam shaft gedung. Air kotor dan air bekas yang telah terkumpul dari masing-masing shaft dialirkan menuju tangki bioseptik yang berada pada sisi kiri dan kanan bangunan. Pemilihan tangki bioseptik sebagai unit pengolahan air buangan, karena unit pengolahan ini kompak dan cukup efektif untuk menyisihkan pencemar yang ada dalam air buangan sehingga efluen air buangan dapat dialirkan langsung menuju drainase umum.

Penggunaan jenis sistem ven tergantung dari perletakan alat plambing dan pipa pembuangan. Jenis sistem ven yang digunakan dalam perancangan yaitu sistem ven tunggal dan sistem ven sirkit. Sistem ven tunggal dipakai karena dapat mencegah hilangnya sekat air dan efek sifon yang terjadi pada lavatory dan sink. Sedangkan sistem ven sirkit digunakan pada alat plambing selain lavatory dan sink. Penggunaan ven 
sirkit ini karena jarak antar pipa air kotor dan air buangan yang berdekatan, sehingga dapat menghemat penggunaan pipa pada sistem ven. Skema sistem penyaluran air buangan dan ven dapat dilihat pada Gambar 1. Jalur perpipaan air buangan untuk tipikal toilet lantai 1 dan isometrinya dapat dilihat pada Gambar 2 dan Gambar 3.
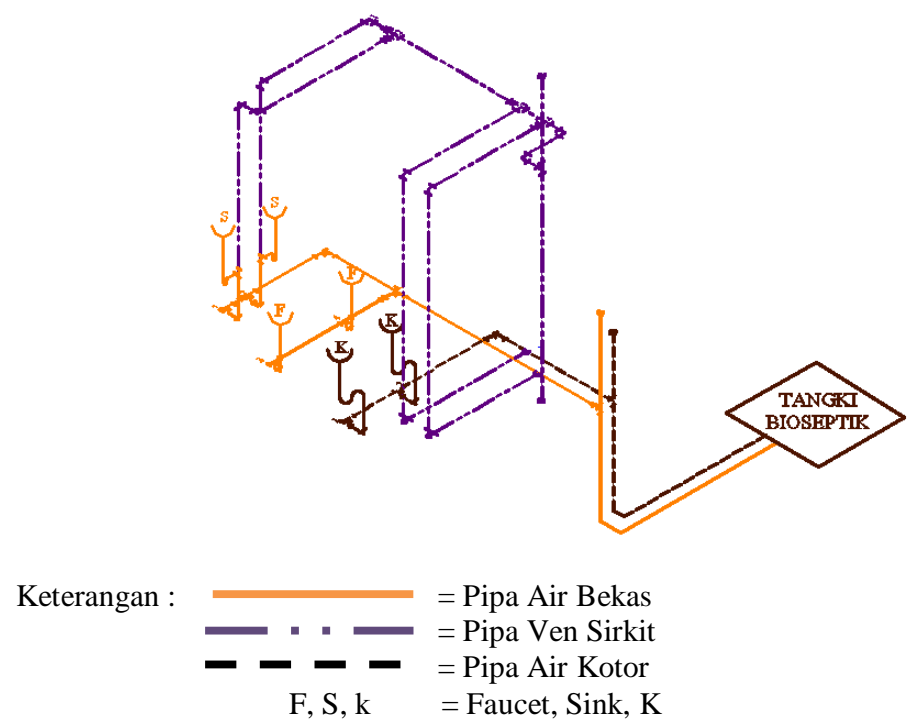

Gambar 1. Skema tipikal sistem perpipaan air buangan dan ven

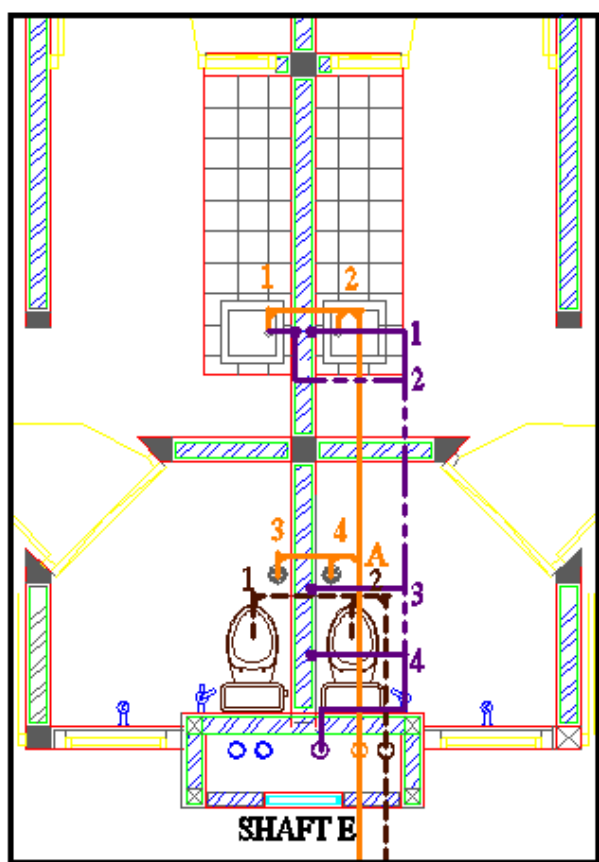

Gambar 2. Tipikal jalur perpipaan air buangan lantai 1 


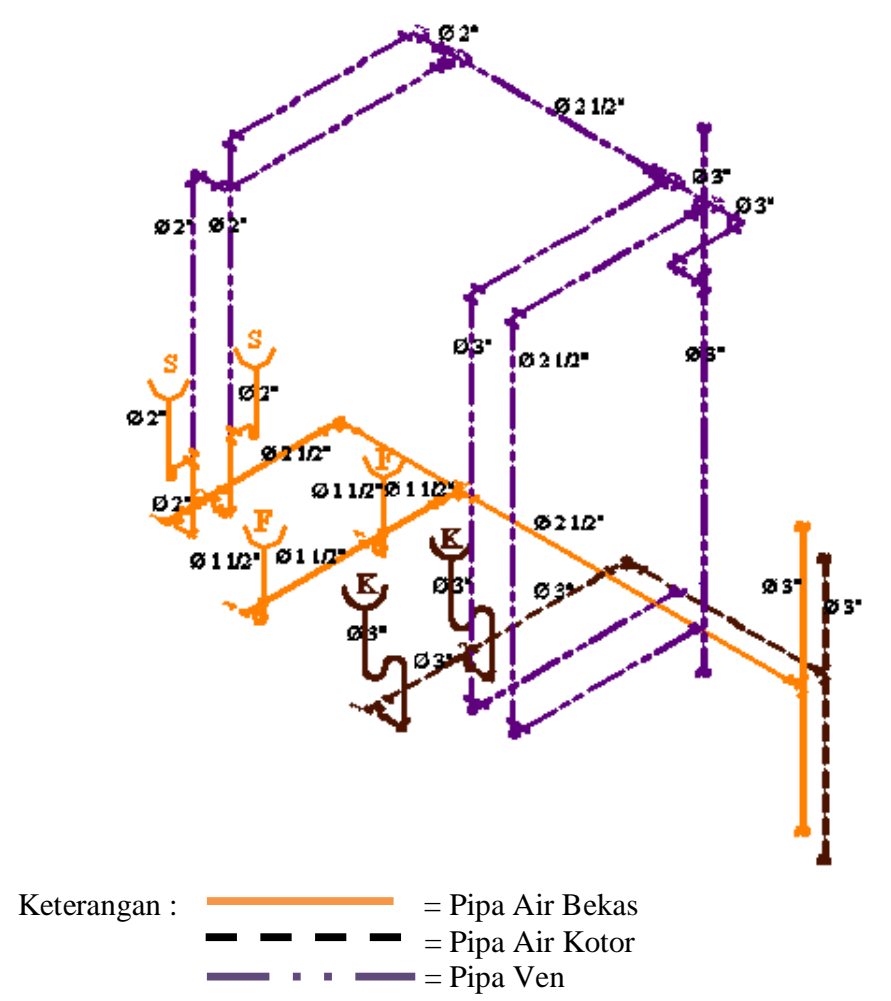

Gambar 3. Isometri perpipaan air buangan lantai 1 Shaft E

\subsubsection{Penentuan Diameter Pipa Air Buangan}

Contoh perhitungan diameter pipa horizontal air buangan lantai 1 shaft E (Gambar 2)

Diameter pipa horizontal air bekas

- Jalur pipa 1-2:

Alat Plambing : 1 Sink

Jumlah unit alat plambing : 4

Diameter minimum : $50 \mathrm{~mm}$

Diameter perhitungan (dari Tabel 4) :50 mm

Diameter desain : $50 \mathrm{~mm}$, karena $\mathrm{D}_{\text {hitung }}=\mathrm{D}_{\text {min }}$

Kemiringan: $1 / 50$, karena $\mathrm{D}<75 \mathrm{~mm}$

- Jalur pipa 2-A:

Alat Plambing : 2 Sink

Jumlah UAP : 8

Diameter minimum : $50 \mathrm{~mm}$

Diameter perhitungan $\left(\mathrm{D}_{\text {hit }}\right)$, dari Tabel 4: $65 \mathrm{~mm}$

Diameter desain : $65 \mathrm{~mm}$, karena $\mathrm{D}_{\text {hitung }}>\mathrm{D}_{\text {min }}$

Kemiringan: 1/50, karena $\mathrm{D}<75 \mathrm{~mm}$

- Jalur pipa A-Shaft:

Alat Plambing : 2 Sink dan 2 Floor drain

Jumlah UAP : $(2 \times 4)+(2 \times 0,5)=9$

Diameter minimum : $50 \mathrm{~mm}$

Diameter perhitungan (dari Tabel 4) : $65 \mathrm{~mm}$

Diameter desain : $65 \mathrm{~mm}$, karena $\mathrm{D}_{\text {hitung }}>\mathrm{D}_{\min }$

Kemiringan: 1/50, karena $\mathrm{D}<75 \mathrm{~mm}$

Diameter pipa horizontal air kotor

- Jalur pipa 1-2:

Alat Plambing : 1 Kloset

Jumlah UAP : 4

Diameter minimum : $75 \mathrm{~mm}$ 
Diameter perhitungan (dari Tabel 4) : $50 \mathrm{~mm}$

Diameter desain : $75 \mathrm{~mm}$, karena $\mathrm{D}_{\text {hitung }}>\mathrm{D}_{\text {min }}$

Kemiringan: $1 / 50$, karena $\mathrm{D}=75 \mathrm{~mm}$

- Jalur pipa 2-Shaft:

Alat Plambing : 2 Kloset

Jumlah UAP : $(2 \times 4)=8$

Diameter minimum : $75 \mathrm{~mm}$

Diameter perhitungan (dari Tabel 4) :65 mm

Diameter desain : $75 \mathrm{~mm}$, karena $\mathrm{D}_{\text {hitung }}>\mathrm{D}_{\text {min }}$

Kemiringan: $1 / 50$, karena $\mathrm{D}=75 \mathrm{~mm}$

Hasil perhitungan diameter pipa horizontal air bekas dan air kotor untuk tipikal lantai 1 shaft $\mathrm{E}$ dapat dilihat pada Tabel 6 dan Tabel 7, sedangkan hasil perhitungan diameter pipa tegak air bekas dan air kotor lantai 1 shaft E dapat dilihat pada Tabel 8.

Tabel 6. Tipikal perhitungan diameter pipa mendatar air bekas lantai 1 Shaft E

\begin{tabular}{ccccc}
\hline Lantai & Shaft & Diameter (inci) & Panjang Pipa $(\mathrm{m})$ & Jenis Pipa \\
\hline \multirow{2}{*}{1} & \multirow{2}{*}{ E } & $11 / 2$ & 0,3 & PVC \\
& & 2 & 0,8 & PVC \\
& & $21 / 2$ & 0,6 & PVC \\
\hline
\end{tabular}

Tabel 7. Tipikal perhitungan diameter pipa mendatar air kotor lantai 1 Shaft E

\begin{tabular}{|c|c|c|c|c|}
\hline Lantai & Shaft & Diameter (inci) & Panjang Pipa (m) & Jenis Pipa \\
\hline 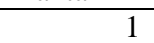 & $\mathrm{E}$ & 3 & 0,9 & PVC \\
\hline
\end{tabular}

Tabel 8. Tipikal perhitungan diameter pipa tegak air bekas dan air kotor lantai 1 Shaft $\mathbf{E}$

\begin{tabular}{ccccc}
\hline Shaft & $\begin{array}{l}\text { Diameter Pipa Tegak } \\
\text { Air Bekas (inci) }\end{array}$ & $\begin{array}{l}\text { Diameter Pipa Tegak } \\
\text { Air Kotor (inci) }\end{array}$ & $\begin{array}{l}\text { Panjang } \\
\text { Pipa (m) }\end{array}$ & Jenis Pipa \\
\hline $\begin{array}{c}\text { E } \\
\text { (Lantai 2- } \\
\text { Lantai 1) }\end{array}$ & 2 & 3 & 3,2 & PVC \\
\hline
\end{tabular}

\subsubsection{Sistem Ven}

Sistem ven berfungsi untuk mengeluarkan gas, pemerataan tekanan dan sirkulasi udara yang terdapat pada pipa air buangan (Gupta and Thawari, 2016). Ujung atas pipa tegak ven berada pada lantai teratas dan terbuka ke udara luar. Jenis pipa ven yang digunakan dalam desain ini adalah pipa ven tunggal dan pipa ven sirkit. Pipa ven tunggal digunakan untuk melayani alat plambing berupa lavatory dan sink. Pipa ven sirkit digunakan untuk alat plambing selain lavatory dan sink. Ukuran pipa ven tegak tidak boleh lebih kecil dibandingkan diameter pipa tegak air buangan. Dimensi pipa ven horizontal dan pipa ven tegak ini ditentukan berdasarkan pada beban unit alat plambing maksimum yang dilayani, panjang pipa ven maksimum dan dimensi pipa air buangan yang dilalui (White, 2007).

\section{Ukuran Pipa Ven}

Contoh perhitungan diameter pipa ven horizontal lantai 1 shaft E pada gambar 2.

- Jalur pipa 1-2:

Alat Plambing : 1 Sink

Jumlah UAP : 4

Diameter air buangan $(\mathrm{Dab}): 50 \mathrm{~mm}$

Panjang pipa : 4,11 m

Diameter pipa ven (dari tabel 5) : $40 \mathrm{~mm}$

Diameter desain : $50 \mathrm{~mm}$, karena Dab > Dven

- Jalur pipa 2-3:

Alat Plambing : 2 Sink

Jumlah UAP : $(2 \times 4)=8$

Diameter air buangan (Dab) : $65 \mathrm{~mm}$ 
Panjang pipa : $5,72 \mathrm{~m}$

Diameter pipa ven (dari tabel 5) : $50 \mathrm{~mm}$

Diameter desain : $65 \mathrm{~mm}$, karena Dab > Dven

- Jalur pipa 3-4:

Alat Plambing : 2 Sink dan 2 Floordrain

Jumlah UAP : $(2 \times 4)+(2 \times 0,5)=9$

Diameter air buangan (Dab) : $65 \mathrm{~mm}$

Panjang pipa : 4,23 m

Diameter pipa ven (dari tabel 5) : $40 \mathrm{~mm}$

Diameter desain : $65 \mathrm{~mm}$, karena Dab > Dven

- Jalur pipa 4-Shaft:

Alat Plambing : 2 Sink, 2 Floordrain dan 2 Kloset

Jumlah UAP : $(2 \times 4)+(2 \times 0,5)+(2 \times 4)=17$

Diameter air buangan (Dab) : $75 \mathrm{~mm}$

Panjang pipa : 4,95 m

Diameter pipa ven (dari tabel 5) : $65 \mathrm{~mm}$

Diameter desain : $75 \mathrm{~mm}$, karena Dab > Dven

Hasil perhitungan diameter pipa horizontal dan pipa tegak ven tipikal pada lantai 1 shaft E dapat dilihat pada Tabel 9 dan Tabel 10.

\subsection{Grease Trap}

Grease trap dipasang pada setiap kitchen sink. Jumlah grease trap yang digunakan pada lantai 1 adalah 10 unit, sedangkan pada lantai 2 sampai 5 masing-masing terdapat 2 unit. Kapasitas grease trap ditentukan berdasarkan laju aliran air buangan pada alat plambing tersebut dengan kriteria sebagai berikut:

- Laju aliran air buangan $(\mathrm{Q} a b)=8 \mathrm{~L} / \mathrm{menit}$

- Waktu detensi $=8$ menit

- Kapasitas grease trap = laju air buangan $\mathrm{x}$ waktu detensi $=0,064 \mathrm{~m}^{3}=64 \mathrm{~L}$

Grease trap yang digunakan adalah grease trap yang terdapat di pasaran berkapasitas $80 \mathrm{~L}$ terbuat dari stainless steel.

Tabel 9. Tipikal perhitungan diameter pipa horizontal ven lantai 1 Shaft E

\begin{tabular}{|c|c|c|c|c|}
\hline Lantai & Shaft & Diameter (inci) & Panjang Pipa (m) & Jenis Pipa \\
\hline \multirow{3}{*}{1} & & 2 & 0,9 & PVC \\
\hline & $\mathrm{E}$ & $21 / 2$ & 3,5 & PVC \\
\hline & & 3 & 1,8 & PVC \\
\hline
\end{tabular}

Tabel 10. Tipikal perhitungan diameter pipa tegak ven (Lantai 1 Shaft E)

\begin{tabular}{lccc}
\hline Shaft & Diameter (inci) & Panjang Pipa (m) & Jenis Pipa \\
\hline E & 3 & 3,2 & PVC \\
\hline
\end{tabular}

\subsection{Tangki Bioseptik Biofilter Anaerob-Aerob}

Tangki bioseptik merupakan instalasi pengolahan air buangan yang direncanakan dapat menampung seluruh air buangan dari dalam gedung. Tangki berjumlah 2 unit, unit pertama terletak pada bagian kiri gedung dan menampung air buangan yang dialirkan dari 6 shaft yaitu shaft A, B, C, J, K, dan L. Tangki bioseptik kedua berada pada bagian kanan gedung dan menampung air buangan yang dialirkan dari shaft E, F, G, H, I, dan J. Hasil pengolahan dari tangki bioseptik ini nantinya telah memenuhi baku mutu air buangan yang diizinkan dan dapat langsung dibuang menuju drainase terdekat. Kapasitas tangki bioseptik dihitung berdasarkan laju aliran air buangan yang masuk yang setara dengan $80 \%$ dari laju aliran air bersih setiap harinya, seperti yang dapat dilihat pada Tabel 11.

Tangki bioseptik unit 1 (kiri gedung) yang digunakan harus mampu menampung air buangan sebesar $40 \mathrm{~m}^{3}$ ) dan 1 unit berkapasitas $50 \mathrm{~m}^{3}$ untuk tangki bioseptik unit 2 (kanan gedung). Tangki bioseptik anaerobik-aerobik ini dilengkapi dengan media biofilter yaitu media lekat mikroorganisme, sehingga dapat meningkatkan kinerja pengolahan dibandingkan dengan septik tank biasa yang hanya mampu men- 
golah air limbah dengan efisiensi penyisihan senyawa organik sekitar 60-70\% (Bounds, 2009) menjadi di atas 90\% (Bandara et al. 2008; Kara 2007). Jika influen air limbah yang harus diolah adalah $220 \mathrm{mg}$ BOD/L (Tchobanoglous et al, 2003), dengan kinerja pengolahan tangki bioseptik sebesar 90\%, dihasilkan efluen dengan konsentrasi $22 \mathrm{mg}$ BOD/L (von Sperling, 2007) yang sudah memenuhi baku mutu air limbah domestik menurut PermenLH No. 68 tahun 2016.

Tabel 11. Perhitungan debit air buangan

\begin{tabular}{|c|c|c|}
\hline Bagian Gedung & $\begin{array}{l}\text { Pemakaian air } \\
\text { rata-rata } L / \text { hari } \\
\left(\mathrm{Q}_{\mathrm{d}}\right)\end{array}$ & $\begin{array}{l}\text { Aliran air bu- } \\
\text { angan L/hari } \\
\left(80 \% \mathrm{Q}_{\mathrm{d}}\right)\end{array}$ \\
\hline $\begin{array}{l}\text { Bagian kiri ke shaft } \\
\text { A, B, C, J, K }\end{array}$ & 49.500 & 39.600 \\
\hline $\begin{array}{l}\text { Bagian kiri ke shaft } \\
\text { E, F, G, H, I, J }\end{array}$ & 55.550 & 44.440 \\
\hline
\end{tabular}

Berdasarkan RSNI Badan Standardisasi Nasional (Badan Litbang PU Departemen PU, 2006) direncanakan dimensi tangki anaerob memiliki lebar $4 \mathrm{~m}$, panjang $8 \mathrm{~m}$ dan tinggi $2,5 \mathrm{~m}$ dengan waktu detensi 2 hari, sedangkan dimensi tangki aerob memiliki lebar $4 \mathrm{~m}$, panjang $4 \mathrm{~m}$ dan tinggi $2,5 \mathrm{~m}$ dengan waktu detensi 1 hari. Media sarang tawon digunakan 50\% dari volume tangki. Kapasitas blower dapat mengalirkan oksigen lebih besar dari $2 \mathrm{~m}^{3} / \mathrm{jam}$ dari tangki kontak aerasi (tangki aerob) dengan tekanan rata-rata $0,15 \mathrm{~kg} / \mathrm{cm} 2$, pengeluaran udara $40 \mathrm{~L} /$ menit. Pembubuh desinfektan dilakukan setelah pengolahan bioseptik Anaerob-aerob dengan dosis $6 \mathrm{mg}$ khlorin/L atau yang setara dengan waktu kontak 15 menit (Davis, 2010). Volume tangki disinfeksi yang dibutuhkan adalah $1 \mathrm{~m}^{3}$.

\section{Kesimpulan}

Sistem plambing air buangan dan ven gedung Rusunawa Mahasiswa Universitas Andalas direncanakan menggunakan sistem terpisah antara air kotor yang berasal dari kloset, dan air bekas yang berasal dari lavatory, sink dan floor drain dengan pengaliran gravitasi. Pipa penyaluran air kotor dan air bekas menggunakan pipa PVC (3 - 4) inci dan (1 1/2-2 1/2) inci. Air kotor dan air bekas disalurkan ke dua buah tangki bioseptik jenis biofilter anaerob-aerob yang berada pada bagian kiri dan kanan lantai dasar gedung dengan kapasitas $40 \mathrm{~m} 3$ dan $50 \mathrm{~m} 3$. Sistem ven yang digunakan adalah sistem ven sirkit untuk floor drain dan kloset serta ven tunggal untuk untuk lavatory dan sink. Pipa yang digunakan adalah pipa PVC berukuran (2 - 4) inci.

\section{Ucapan Terima Kasih}

Penelitian ini didanai melalui Program Kegiatan Penelitian Dosen Jurusan Teknik Lingkungan Fakultas Teknik Dana PNBP Universitas Andalas No. 016/UN.16.09.D/PL /2016.

\section{Daftar Pustaka}

American Society of Plumbing Engineers. (2012). 4 Plumbing Engineering Design Handbook.

Badan Litbang PU Departemen PU. (2006). "Tata Cara Perencanaan Dan Pemasangan Tangki Biofilter Pengolahan Air Limbah Rumah Tangga Dengan Tangki Biofilter Persyaratan.” : 1-17.

Bandara, W M K R T W, K G N Nanayakkara, P Premananth, and D R I B Werellagama. (2008). "Development of an Upflow Anaerobic Biological Filter for Domestic Use in Tropical Countries." (8).

Bounds, TR. (2009). "Design and Performance of Septic Tanks." Site Characterization and Design of On-Site Septic Systems: 217-217-18.

Davis, Mackenzie L. (2010). Water and Wastewater Engineering: Design Principles and Practice. McGraw-Hill Companies, Inc.

Gupta, Laxmi C., and Samruddhi Thawari. (2016). "Plumbing System in High Rise Building.” In International Journal for Innovative Research in Science \& Technology|, www.ijirst.org.

Kara, Melik. (2007). "Anaerobic Filter Performance by Anaerobic Filter Performance at Different Conditions." Dokus Eylül University.

Kementerian Lingkungan Hidup dan Kehutanan Republik Indonesia. (2016). PermenLH 68 Tahun 2016 Baku Mutu Air Limbah Domestik. kalimantan.menlhk.go.id/index.php/public/page/download/1162.

Mara, David Duncan. (2004). Domestic Wastewater Treatment in Developing Countries. London: Earthscan. 
Morimura dan Noerbambang. (2000). Perancangan Dan Pemeliharaan Sistem Plambing. Edisi 4. Jakarta: Pradnya Paramita.

von Sperling, Marcos. (2007). Basic Principles of Wastewater Treatment. London: IWA Publishing. Standar Nasional Indonesia. 2000. SNI 03 - 6481 - 2000 Sistem Plambing - 2000.

2005. "Tata Cara Perencanaan Sistem Plambing." Standar Nasional Indonesia (SNI)-03-70652005.

Tchobanoglous, George et al. (2003). Wastewater Engineering: Treatment Disposal Reuse. 4 th Editi. McGraw-Hill Education.

U.S. Department of Veterans Affair. (2014). Plumbing Design Manual. Office of Construction \& Facilities Management. https://www.wbdg.org/FFC/VA/VADEMAN/dmplbg.pdf.

White, Steven. 2007. "Active Air Pressure Suppression of Drainage Systems - from Research to the Marketplace." In 33rd International Symposium: Water Supply and Drainage for Buildings, eds. K De Cuyper et al. Brno, Czech Republic, 503. www.ta-service.cz. 